\title{
Economic analysis of dairy cattle farms under town milk supply scheme in Jorhat district of Assam
}

\author{
Shweta Priyamvada and BK Mishra
}

Received: 04 March 2019 / Accepted: 12 June 2019 / Published online: 22 June 2019

(c) Indian Dairy Association (India) 2019

\begin{abstract}
Dairy development has assumed significant importance in the rural economy of India due to its immense potential for supplementing income and employment generation for the rural people. Recently, under the Town Milk Supply Scheme, Government of Assam has attempted to increase the milk production under organized sector. Present study is an attempt to study the economics of organized dairy cattle farms in Jorhat district of Assam started under the scheme. The study was done by selecting 100 commercial dairy farmers under organized dairy sector in Jorhat district of Assam.In the study area 81 dairy farmer found to be small category, 10 dairy farmers were identified to be in medium category and nine dairy farmers were in large category of dairy farmer.The total milk production in 100 sample dairy farms was reported as 3445 litres per day with average milk production of 8.79 litres per day per milch animal. The total milk production per day per farm in small dairy farms was observed as 21.57 litres, in medium dairy farms as 58.7 litres and in large as 123.44 litres. Overall the average milk production per farm in 100 sample households was estimated to be 34.45 litres per farm per day. With more than 94 percent of the investments the dairy cattle's especially the cross breed and Indian breed accounted for the maximum share of the investments.A return of Rs. 812.68 per farm per day in small
\end{abstract}

Shweta Priyamvada and BK Mishra ( $\square)$

Department of Rural Development and Agricultural Production, North-Eastern Hill University, Tura Campus, Tura-794 002, Meghalaya, India

Email: birendramishra14@gmail.com category of dairy farms, Rs. 2210.85 per farm per day in medium category of dairy farms, Rs. 4497.81 per farm per day in large category of dairy farms was observed. The income from sale of milk constituted the maximum proportion of the income (more than 98 percent) in all the categories of the dairy farm. The returns from sale of manure/cow dung and male calves also contributed to the total income but in minimal way. It was observed that the profit per farm per day increased from Rs. 248.53 from small farms to Rs. 690.86 in medium farms to Rs. 773.9 in large dairy farms.Feed cost influence was positive and significant. Hence, increase in the use of feed would increase the revenue from dairy farms by 1.66 percent.

Keywords: Cost and Returns, Dairy farmers, Organized Dairy Sector, Resource Use Efficiency

\section{Introduction}

Dairying in India, over the years, apart from insuring nation's nutrition, has been recognized as an instrument for social and economic development. Dairy has an important role in improving the overall economic conditions of rural India (Dhanabalan, 2009). There are proven evidences that dairy farming has emerged as a major allied enterprise for supplementing the income of farmers (Singh and Joshi, 2008; Ramakrishnappa, 2006). There are also evidences that dairy sector contributes significantly in generating employment opportunities and supplementing the income of small and marginal farmers by providing them food security (Kakaty and Gogoi, 2001). Thus, dairy development has assumed significant importance in the rural economy of India due to its immense potential for supplementing income and employment generation for the rural people. As a result, the milk production in India, which was around 17-22 million tonnes in the 1960s, has increased to 165.4 million tonnes in 2016-17 (Department of Animal Husbandry, Dairying \& Fisheries, Ministry of Agriculture, GoI). India's milk production is estimated to have increased by $6.6 \mathrm{per}$ cent from 165.4 million tonnes during 2016-17 to 176.35 million tonnes during 2017-18 (GoI, 2018). In fact India ranks first in the world in milk production. As per the vision 2022 document the projected milk production by $2021-22$ is 254.5 million tonnes. Similarly, per capita availability of milk has increased from 178 grams per day in 1991-92 to 307 grams in 2013-14 to 355 grams in 
the year 2016-17. Similarly, the income of dairy farmers increased by 23.77 percent in 2014-17 compared to 2011-14 (The Hindu, $28^{\text {th }}$ December, 2017; Department of Animal Husbandry, Dairying \& Fisheries, Ministry of Agriculture, GoI, 2017).

With 2.4 per cent of the country's total geographical area and 2.6 per cent population of the Country, the State of Assam is situated in the North-Eastern region of India. The State has total cropped area of 40.83 lakh hectares (2014-15) with net sown area of 28.27 lakh hectares. Though agriculture is considered as the mainstay of the economy of Assam and agriculture and allied activities in Assam do continue to be the dominant sources of livelihood for majority of its people, it is also a fact that agriculture in the State is characterized by low level of productivity due to recurring natural calamities, low level of mechanization, inadequate availability of quality inputs, poor soil health, low level of assured irrigation and inadequate marketing infrastructure. In fact about 83 per cent of the total land holdings are small and marginal and is a major concern for formulation of any agricultural development strategy. This necessitates the importance of allied sectors like dairy in States economy (Kakaty and Das, 2017).

Interestingly, in the state of Assam, organized development of dairy processing infrastructure was initiated even before the launch of OF (Operation Flood) Phase-I. The first processing plant in the state was established at Jorhat in 1966 with daily milk processing capacity of 5,000 litres (Sirohi et al. 2009). However, in spite of that, the present estimated production of milk in the district is about 70000 litres per day as against the total demand of 160000 litres per day and this gap is bridged by importing milk from Dimapur and other places (Progress report of dairy development in Jorhat and Golaghat District, Town Milk Supply Scheme, Jorhat, 2013). Recently, under the Town Milk Supply Scheme, Government of Assam has attempted to increase the milk production under organized sector in the district. Present study is an attempt to study the economics of organized dairy cattle farms in Jorhat district of Assam started under the Town Milk Supply Scheme, Government of Assam. The findings of this study shall help in the formulation of a comprehensive dairy development plan which may lead to bridge the existing demandsupply gap of milk in the district.

\section{Materials and methods}

Jorhat district in State of Assam was purposively selected as in spite of the first processing plant of the State being established in 1966 (Sirohi et al. 2009), there is still huge demand supply gap in the district (Progress report of dairy development in Jorhat and Golaghat District, Town Milk Supply Scheme, Jorhat, 2013). Total geographical area of Jorhat district is $2,859.35 \mathrm{sq} \mathrm{km}$. equivalent to 3.63 percent of the state. The district consists of 3 civil subdivisions, 8 development blocks and 111 Gaon panchayats with 866 revenue villages. Jorhat district consists of one municipality and 6 towns. The study was done by selecting
100 commercial dairy farmers under organized dairy sector in Jorhat district of Assam. The organized sector sample farmers were drawn from randomly selected DUSS namely Surabhi DUSS, Chitralekha DUSS, Sonali DUSS, Titabor, Swarnadhenu DUSS, Amrit DUSS, Paschim Titabor DUSS, Panchamukhi DUSS, Dahikhur Bhuyanchuk DUSS, Lakhimi DUSS, Lachit DUSS, Phesual DUSS. The random selection was done by preparing the list of dairy farms and dairy farmers operational under Town Milk Supply Scheme, Jorhat. The list was taken from the Office of the Assistant Dairy Development Officer, Town Milk Supply Scheme, Rowriah, Jorhat.

To achieve the specific objectives of this study, necessary data were collected from dairy farmers through personal interviews by using schedules. The schedules were constructed after following an extensive review of literature, discussion with experts and pilot survey. Information was sought on the milk production practices adopted by the milk farmers in the study area and the average price farmers received for the milk. The time series data for different periods were collected from the State level reports published by Directorate of Economics and Statistics, Government of Assam. "Basic Statistics of NER" published by North Eastern Council, Shillong was considered. Secondary data was also collected from various websites and report of various committees, etc.

Both tabular and functional analyses with econometrical tools were utilized for the analysis of the data and logical interpretation of the different aspects and results of the study.The Cumulative Square Root frequency procedure of stratum construction (Dalenius and Hodges ,1959) was carried out for the division of dairy farmers into L strata. To understand the changes in milk production, growth rate and stability examination was done by working out compound annual growth rate, standard deviation and coefficient of variation. To understand the economics of milk production, the cost of milk production and capital investment was estimated. The interest on the fixed capital was worked out based on prevailing rate of interest i.e. 7 percent per annum (RBI, 2016, 17). Depreciation on fixed asset was calculated separately for milch animals, cattle shed (the cowsheds found in the study area were semi pucca- buildings in nature), machinery and equipments (Ghule et al. 2012) as given below:

Crossbred cows- 8 per cent (productive life 12.5 years),

Local cows- 10 percent (productive life 10 years)

Depreciation rates forsemi- pucca building was worked out as 5 percent, for Bicycle was 8.33 percent, for Chaffcutter as 10 percent and for Milk cans and patty items as 20 percent.

The resource-use efficiency of the inputs used by the dairy farms was estimated using Cobb-Douglas (CD), formula given by 
Charles Cobb and Paul Douglas in 1928 production function, as given below.

$$
\mathrm{Y}=\mathrm{a} X 1^{\mathrm{b} 1} \mathrm{X} 2^{\mathrm{b} 2} \mathrm{X} 3^{\mathrm{b} 3}
$$

Where, $\mathrm{Y}$ is the revenue from farm (income from selling of milk and male calf and cow dung in rupees per day); X1, X2 and X3 denotes feed cost, miscellaneous expenditure and labour cost in rupees per day.

The estimated coefficients of significant independent variables were used to compute the marginal value products (MVP).

$$
\text { where, } \mathrm{MVP}_{\mathrm{i}}=\hat{a} i \frac{\bar{Y}}{\overline{X_{i}}}
$$

Here, $\mathrm{MVPi}=$ Marginal value product of the $\mathrm{i}^{\text {th }}$ input, $\bar{Y}=$

Geometric mean of the value of output, $\overline{X_{i}}=$ Geometric mean of the $\mathrm{i}^{\text {th }}$ input, $\hat{a} \mathrm{i}=$ Estimated co-efficient (or) elasticity of the $\mathrm{i}^{\text {th }}$ input.

The economic efficiency of resource use was estimated as

$\mathrm{r}=\frac{M V P}{M F C}$

where, $\mathrm{MFC}_{\mathrm{i}}=$ Marginal Factor Cost (i.e. cost of one unit of a particular resource)
Decision rule: If $r=1$, resource is efficiently utilized; $r>1$, resource is underutilized and $\mathrm{r}<1$, resource is over utilized

Economic optimum was taken place where $\mathrm{MVP}=\mathrm{MFC}$. If $\mathrm{r}$ is not equal to 1, it is suggested that resource are not efficiently utilized. Adjustments could be therefore, be made in the quantity of input used and costs in the production process to restore $\mathrm{r}=1$.

\section{Results and discussion}

\section{Distribution of sample dairy farms}

Table 1 presents the distribution of sample dairy farms. As mentioned earlier, data were collected from 100 sample dairy farms from organized dairy sector. Based on Cumulative Square Root frequency of stratification (Jaiswal and Singh, 2015; Singh, Chauhan and Yogi, 2014; Ghule, Verma, Cahuhan and Sawale, 2012 and Khoveio, Jain and Das, 2016), the sample dairy farms were grouped into three categories viz. small (up to 5 milch animals), medium (6-10 milch animals) and large (11 milch animals and above). In organized dairy sector 81 dairy farmer found to be small category, 10 dairy farmers were identified to be in medium category and nine dairy farmers were in large category of dairy farmer. Here it is to be mentioned that the dairy farmers in organized dairy sector have taken dairy farming under the initiative of TMSS (Town Milk Supply Scheme) very recently with one or two dairy cows.

\section{Distribution of cattle in sample dairy farms}

Table 2 presents the distribution of cattle in sample dairy farms in organized dairy sector as 213 milch cows, 17 dry cows, 13 heifer

Table 1 Distribution of sample dairy farms

\begin{tabular}{llllc}
\hline Sl. No & Category of dairy farmers & \multicolumn{3}{c}{ Sample size (in numbers) } \\
\cline { 3 - 5 } & & Organised dairy sector & Unorganised dairy sector & Total \\
\hline 1 & Small (up to 5 milch animals) & 81 & 8 & 89 \\
2 & Medium (6-10 milch animals) & 10 & 42 & 52 \\
3 & Large (11 milch animals and above) 9 & 50 & 59 \\
4 & All & 100 & 100 & 200 \\
\hline
\end{tabular}

Sub: Authors Calculations Based on Field Survey

Table 2 Distribution of cattle in dairy farms

\begin{tabular}{llllll}
\hline Sl. No. & Cattle & \multicolumn{4}{c}{ Categories of Dairy Farms } \\
\cline { 3 - 6 } & & Small & Medium & Large & Total \\
\hline 1 & Milch Cow & 213 & 63 & 116 & 392 \\
2 & Dry Cow & 17 & 04 & 31 & 52 \\
3 & Heifer & 13 & 07 & 11 & 31 \\
4 & Calf & 33 & 09 & 24 & 66 \\
& All & 276 & 83 & 182 & 541 \\
\hline
\end{tabular}

Sub: Authors Calculations Based on Field Survey 
and 33 calves by small category of dairy farms. Medium category of dairy farms reported 63 milch cows, 4 dry cows, 7 heifer and 9 calves. Large category of dairy farms reported 116 milch cows, 31 dry cows, 11 heifer and 24 calves. The entire 100 sample dairy farms 392 milch cows, 52 dry cows, 31 heifer and 66 calves were noted. A total of 541 cattle were observed in 100 sample dairy farms with 276 in small

\section{Distribution of cattle breeds in sample dairy farms}

Table 3 presents the distribution of cattle breeds in sample dairy farms in organized dairy sector. Three categories of cattle breeds were observed in sample dairy farms. These are local (nondescript), Indian breed and Crossbreed. In small category of dairy farms two cows of local breed (two milch cows), 11 cows of Indian breed (11 milch cows) and 217 cows of cross breed (200 in milch and 17 in dry) were reported. In medium category of dairy farms four cows of local breed, three cows of Indian breed and 60 cows of cross breed (56 in milch and four in dry) were reported. In large category of dairy farms 5 cows of Indian breed ( 5 milch cows) and 142 cows of cross breed (111 in milch and 31 in dry) were reported. Overall in 100 sample dairy farms 6 local, 19 Indian breed and 419 crossbreed (367 in milch and 52 in dry) were reported.

\section{Milk production by sample dairy farms}

Table 4 presents the milk production information by sample dairy farms of the organized dairy sector. The total milk production in
81 samples of small dairy farms was reported as 1747 litres per day with average milk production of 8.20 litres per day per milch animal. The total milk production in 10 samples of medium dairy farms was reported as 587 litres per day with average milk production of 9.32 litres per day per milch animal. The total milk production in nine samples of large dairy farms was reported as 111 litres per day with average milk production of 9.58 litres per day per milch animal. The total milk production in 100 sample dairy farms was reported as 3445 litres per day with average milk production of 8.79 litres per day per milch animal. The total milk production per day per farm in small dairy farms was observed as 21.57 litres, in medium dairy farms as 58.7 litres and in large as 123.44 litres. Overall the average milk production per farm in 100 sample households was estimated to be 34.45 litres per farm per day. The total milk production from crossbreed per day per farm in small dairy farms was observed as 1609 litres, in medium dairy farms as 543 litres and in large as 1051 litres. Overall the total milk production from cross breed per day per farm in 100 sample households was estimated to be 3203 litres per day. The average milk yield from crossbreed per day per milch animal in small dairy farms was observed as 8.05 litres, in medium dairy farms as 9.70 litres and in large as 9.47 litres. Overall the average milk production from cross breed per day per milch in 100 sample households was estimated to be 8.73 litres per milch animals. The total milk production from Indian breed per day per farm in small dairy farms was observed as 134 litres, in medium dairy farms as 36 litres and in large as 60 litres. Overall the total milk production from Indian breed per day per farm in 100 sample households

Table 3 Distribution of cattle breeds

\begin{tabular}{|c|c|c|c|c|c|c|c|c|c|}
\hline \multirow[t]{3}{*}{ Sl. No. } & \multirow[t]{3}{*}{ Breeds } & \multicolumn{8}{|c|}{ Category of Sample Dairy Farms } \\
\hline & & \multicolumn{2}{|l|}{ Small } & \multirow{2}{*}{$\begin{array}{l}\text { Medium } \\
\text { Milch }\end{array}$} & \multirow{2}{*}{$\overline{D r y}$} & \multirow{2}{*}{$\frac{\text { Large }}{\text { Milch }}$} & & \multirow{2}{*}{$\begin{array}{l}\text { Total } \\
\text { Milch }\end{array}$} & \multirow[b]{2}{*}{ Dry } \\
\hline & & $\overline{\text { Milch }}$ & Dry & & & & Dry & & \\
\hline$\overline{1}$ & $\overline{\text { Local (Non-Descript) }}$ & 02 & 0 & 04 & 0 & 0 & 0 & 06 & 0 \\
\hline 2 & Indian Breed & 11 & 0 & 03 & 0 & 05 & 0 & 19 & 0 \\
\hline 3 & Crossbreed & 200 & 17 & 56 & 04 & 111 & 31 & 367 & 52 \\
\hline & Total & 213 & 17 & 63 & 04 & 116 & 31 & 392 & 52 \\
\hline
\end{tabular}

Sub: Authors Calculations Based on Field Survey

Table 4 Milk production in dairy farms

\begin{tabular}{|c|c|c|c|c|c|c|c|c|c|c|c|}
\hline \multirow[t]{2}{*}{ S1. No. } & \multirow[t]{2}{*}{$\begin{array}{l}\text { Dairy } \\
\text { Farms }\end{array}$} & \multirow[t]{2}{*}{$\begin{array}{l}\text { Number } \\
\text { of } \\
\text { Dairy } \\
\text { Farms }\end{array}$} & $\begin{array}{l}\text { Total } \\
\text { Produ } \\
\text { /Day }\end{array}$ & & & & \multirow[t]{2}{*}{$\begin{array}{l}\text { Total Milk } \\
\text { Production } \\
\text { per Day } \\
\text { per Farm } \\
\end{array}$} & \multicolumn{4}{|l|}{$\begin{array}{l}\text { Average Milk } \\
\text { Yield/Day } \\
\text { /Milch } \\
\text { Animal } \\
\end{array}$} \\
\hline & & & $\mathrm{CB}$ & IB & ND & Total & & $\mathrm{CB}$ & IB & ND & Total \\
\hline 1 & Small & 81 & 1609 & 134 & 4 & 1747 & 21.57 & 8.05 & 12.18 & 2.00 & 8.20 \\
\hline 2 & Medium & 10 & 543 & 36 & 8 & 587 & 58.7 & 9.70 & 12.00 & 2.00 & 9.32 \\
\hline 3 & Large & 9 & 1051 & 60 & 0 & 111 & 123.44 & 9.47 & 12.00 & 0.00 & 9.58 \\
\hline 4 & Total & 100 & 3203 & 230 & 12 & 3445 & 34.45 & 8.73 & 12.11 & 2.00 & 8.79 \\
\hline
\end{tabular}

Note: $C . B=$ Cross Breed; $I B=$ Indian Breed; $N D=$ Non Descript

For calculation of average milk production/day/milch animal, only milch animals under lactation were considered and the dry animals were not considered 
was estimated to be 230 litres per day which is very less compared to production from cross breed. The average milk yield from Indian breed per day per milch animal in small dairy farms was observed as 12.18 litres, in medium and large dairy farms as 12.00 litres. Overall the average milk production from Indian breed per day per milch in 100 sample households was estimated to be 12.11 litres per milch animals. The total milk production from non descript per day per farm in small dairy farms was observed as 4 litres and in medium dairy farms as 8 litres. Overall the total milk production from non descript per day per farm in 100 sample households was estimated to be 12 litres per day. The average milk yield from non descript per day per milch animal in both small and medium dairy farms was observed as 2 litres. Overall the average milk production from non descript per day per milch in 100 sample households was also estimated to be 2 litres per milch animals.

\section{Investment pattern on dairy farms}

Table 5 presents the investment pattern on commercial dairy farms in organized dairy sector. The investments were presented in terms of rupees per farm per day for small, medium and large categories of dairy farms. With more than 94 percent of the investments the dairy cattle's especially the cross breed and Indian breed accounted for the maximum share of the investments. Earlier studies on economics of milk production (Pant and Karanjkar, 1965; Chattraji and Singh, 1989; Chand et al. 2002;
Singh 2008 and Ghule et al. 2012) also indicated that the share of investment on animal always remains the highest followed by buildings and equipment. Taking productive life of cattles into consideration, the investment per farm in cross and Indian breed was estimated to be Rs. 660.23 per farm per day in small dairy farms, Rs. 1623.48 in medium dairy farms per day and Rs. 4247.34 per day in large category of dairy farms. Investment in local breed was observed to be only Rs. 1.12 per farm per day and Rs. 9.10 per farm per day in medium category of dairy farms. In terms of percentage of total investment, it was observed that investment in cross breed and Indian breed was 93.97 percent of total investment in small dairy farms, 95.08 percent of total investment in medium dairy farms and 96.71 percent in large dairy farms. This is seriously higher from the findings of Ghule et al. (2012) where they reported the share of dairy animals in total investment as 51.28 percent on small farms, 55.19 percent on medium farms and 70.12 percent in case of large farms. Overall it was observed that 95.09 percent of total investment was in cross breed and Indian breed in the sample of 100 dairy farms in organized dairy sector. The investment in local breed was 0.16 percent of total investment in small dairy farms and 0.53 percent of total investment in medium dairy farms. Overall it was observed that 0.16 percent of total investment was in local breed in. the sample of 100 dairy farms in organized dairy sector.

Taking building (cattle shed and stores) into consideration, the investment per farm in was estimated to be Rs. 13.83 per farm per

Table 5 Investment pattern

\begin{tabular}{|c|c|c|c|c|c|}
\hline \multirow[t]{2}{*}{ Sl No } & \multirow[t]{2}{*}{ Items } & \multicolumn{3}{|c|}{ Category of Dairy Farms } & \multirow[b]{2}{*}{ Pooled } \\
\hline & & Small & Medium & Large & \\
\hline \multirow[t]{4}{*}{$\overline{\mathrm{A})}$} & \multicolumn{5}{|l|}{ Animals } \\
\hline & i) Cross Breed & 660.23 & 1623.48 & 4247.34 & 1079.40 \\
\hline & \multirow[t]{2}{*}{ ii) Local Breed } & 1.12 & 9.10 & 0.00 & 1.81 \\
\hline & & $(0.16)$ & $(0.53)$ & $(0.00)$ & $(0.16)$ \\
\hline \multirow[t]{2}{*}{ B) } & Building (Cattle & 13.83 & 20.27 & 33.00 & 16.20 \\
\hline & Shed and Stores) & $(1.97)$ & $(1.19)$ & $(0.75)$ & $(1.43)$ \\
\hline \multirow[t]{9}{*}{ C) } & \multicolumn{5}{|c|}{ Machinery, Equipments and Others } \\
\hline & \multirow[t]{2}{*}{ (i) Bicycle } & 3.79 & 3.84 & 3.20 & 3.74 \\
\hline & & $(0.54)$ & $(0.22)$ & $(0.07)$ & $(0.33)$ \\
\hline & and Patty Items & $(3.36)$ & $(2.01)$ & $(1.53)$ & $(2.52)$ \\
\hline & \multirow[t]{2}{*}{ Total (i to iii) } & 27.39 & 54.60 & 111.40 & 37.67 \\
\hline & & & $(3.20)$ & $(2.54)$ & $(3.32)$ \\
\hline & \multirow{3}{*}{\multicolumn{2}{|c|}{$\begin{array}{l}\text { Total Investment or } 702.57 \\
\text { Fixed Capital or Non- }(100.00) \\
\text { Recurring Expenditures }(\mathrm{A}+\mathrm{B}\end{array}$}} & 1707.45 & 4391.74 & 1135.08 \\
\hline & & & $(100.00)$ & $(100.00)$ & $(100.00)$ \\
\hline & & & & & \\
\hline
\end{tabular}

Note: Figures in parentheses are the percentage to total investment.

Sub: Authors Calculations Based on Field Survey 
day in small dairy farms, Rs. 20.27 in medium dairy farms per day and Rs. 33.00 per day in large category of dairy farms. Overall investments in buildings were estimated as Rs. 16.20 per farm per day. In terms of percentage of total investment, it was observed that investment in buildings was 1.97 percent of total investment in small dairy farms, 1.19 percent of total investment in medium dairy farms and 0.75 percent in large dairy farms. Overall it was observed that 1.43 percent of total investment was in buildings in the sample of 100 dairy farms in organized dairy sector. About 3.32 percent of the total investment accounted for machinery, equipment and other similar items. In small dairy farms this investment accounted for 3.90 percent, in medium this investment accounted for 3.20 percent and in large dairy farms accounted for 2.54 percent of total investment. Thus, in contrast to the observations of Pant and Karanjkar, 1965; Chattraji and Singh, 1989; Chand et al. 2002; Singh 2008 and Ghule et al. 2012, the share of investment on equipment was found to be higher than that of buildings. The total investment in small dairy farms was calculated as Rs. 702.57, in medium dairy farms as Rs. 1707.45 and in large dairy farms as Rs. 4391.74.

\section{Economics of milk production}

Table 6 presents the cost incurred by different categories of commercial dairy farms in milk production in organised dairy sector. The various cost components were categorized into two categories- operational fixed cost or overhead cost per day and working capital or recurring expenditure. The operational fixed cost or overhead cost per day per farm of Rs. 60.17 in small category of dairy farms, Rs. 259.03 in medium category of dairy farms and Rs. 665.41 in large category of dairy farms. Overall for the entire sample Rs. 173.25 found to be spent as operational fixed cost or overhead cost per day per farm. The depreciation on cross breed \& Indian breed accounted for the majority of the share of operational fixed cost or overhead cost per day per farm with Rs. 52.82 in small, Rs. 129.88 in medium, Rs. 339.79 in large category of dairy farms. Since the maximum investment was for the cross breed and Indian breed, thus, obviously, the

Table 6 Cost incurred by dairy farms

(Rupees per Farm per Day)

\begin{tabular}{|c|c|c|c|c|c|}
\hline$\overline{\text { Sl. No }}$ & Cost Components & & Herd Size & & \\
\hline$\overline{\mathrm{A}}$ & Operational Fixed Cost or Overhead Cost per Day & Small & Medium & Large & Pooled \\
\hline a) & Depreciation on Cross Breed \& Indian Breed & 52.82 & 129.88 & 339.79 & 86.35 \\
\hline b) & Depreciation on Local Breed & 0.11 & 0.91 & 0.00 & 0.18 \\
\hline c) & Depreciation on Building (Cattle Shed and Stores) & 0.69 & 1.01 & 1.65 & 0.81 \\
\hline d) & Depreciation on Machinery, Equipments and Other & & & & \\
\hline & Bicycle & 0.32 & 0.32 & 0.27 & 0.31 \\
\hline & Chaff-Cutter & 0.00 & 1.64 & 4.11 & 0.53 \\
\hline & Milk Cans and Patty Items & 4.72 & 6.87 & 13.42 & 5.72 \\
\hline & Total Depreciation on Equipment & 5.03 & 8.83 & 17.80 & 6.56 \\
\hline e) & Interest on Fixed Capital (Subsidised) & 1.51 & 118.40 & 306.18 & 79.34 \\
\hline & Total Operational Fixed Cost Per Day & 60.17 & 259.03 & 665.41 & 173.25 \\
\hline B & Working Capital or Recurring Expenditure & & & & \\
\hline a) & Expenditure on Feed & & & & \\
\hline & $\begin{array}{l}\text { Feeding During Lactation Period (Green } \\
\text { Fodder, Dry Fodder and Concentrates) }\end{array}$ & 436.71 & 1038.90 & 2166.84 & 652.64 \\
\hline & $\begin{array}{l}\text { Feeding During Dry Period(Green Fodder, } \\
\text { Dry Fodder and Concentrates) }\end{array}$ & 19.30 & 38.48 & 334.43 & 46.77 \\
\hline & $\begin{array}{l}\text { Feed of Heifers (Green Fodder, Dry Fodder } \\
\text { and Concentrates) }\end{array}$ & 14.54 & 63.44 & 110.76 & 28.09 \\
\hline & $\begin{array}{l}\text { Feed of Calf's (Green Fodder, Dry Fodder } \\
\text { and Concentrates) }\end{array}$ & 14.26 & 31.50 & 93.33 & 23.10 \\
\hline & Total Expenditure on Feed & 484.81 & 1172.32 & 2705.37 & 750.61 \\
\hline b) & Expenditure on Veterinary Services & 18.39 & 44.80 & 109.14 & 29.20 \\
\hline c) & Expenditure on Labour & 0.00 & 16.67 & 177.78 & 17.67 \\
\hline d) & Miscellaneous Expenses & 11.16 & 27.17 & 66.21 & 17.71 \\
\hline & Total Recurring Expenditure & 514.35 & 1260.96 & 3058.50 & 815.19 \\
\hline $\mathrm{C}$ & Operational Cost Per Day & & & & \\
\hline a) & Total Operational fixed cost per Day & 60.17 & 259.03 & 665.41 & 173.25 \\
\hline b) & Total Recurring Expenditure per Day & 514.35 & 1260.96 & 3058.50 & 815.19 \\
\hline & Total Operational Cost Per Day & 574.52 & 1519.99 & 3723.91 & 988.44 \\
\hline
\end{tabular}

Note: Subsidy of Rs. 58480.00 per farm under Scheme for two animals 
depreciation on cross breed and Indian breed was having maximum share of the operational fixed cost per day in all the category of dairy farms.

As far as working capital or recurring expenditure is concerned, it was observed that Rs. 514.35 was spent by small dairy farms per day, Rs. 1260.96 by medium dairy farms per day, Rs. 3058.50 by large dairy farms per day. The pooled recurring expenditure was estimated as Rs. 815.19 per farm day. The expenditure on feed accounted for the majority of the share of recurring expenditure per day per farm with Rs. 484.81 in small, Rs. 1172.32 in medium, Rs. 2705.37 in large category of dairy farms. Since, the small farms mostly run by the family members, whoever is available at that time, thus, no expenditure on labours in small farms was found. Taking both the categories of costs together, the total operational cost per day per farm was found as Rs. 574.52 in small category of dairy farms, Rs. 1519.99 in medium category of dairy farms, Rs. 3723.91 in large categories of dairy

Table 7 Return per farm per day

\begin{tabular}{lllllc}
\hline SI.No. & Return Components & \multicolumn{3}{c}{ HerdSize category } & Pooled \\
\cline { 3 - 5 } & & Small & Medium & Large & 1276.53 \\
a) & Sale of Milk & 812.68 & 2185.60 & 4441.11 & $(98.76)$ \\
& & $(98.74)$ & $(98.86)$ & $(98.74)$ & 10.67 \\
b) & Sale of Manure/Cow dung & 6.72 & 16.37 & 39.89 & $(0.83)$ \\
& & $(0.82)$ & $(0.74)$ & $(0.89)$ & 5.36 \\
c) & Sale of Male Calves & 3.65 & 8.88 & 16.80 & $(0.41)$ \\
& & $(0.44)$ & $(0.40)$ & $(0.37)$ & 1292.56 \\
& Total & 823.05 & 2210.85 & 4497.81 & $(100.00)$ \\
\hline
\end{tabular}

Note: Figures in parentheses are the percentage of gross cost.

Source: Authors Calculations Based on Field Survey

Table 8 Cost and return analysis

\begin{tabular}{lllllc}
\hline Sl. No. & Cost and Return Components & \multicolumn{4}{l}{ Herd Size category } \\
\cline { 3 - 5 } & & Small & Medium & Large & Pooled \\
\hline a) & Number of Farms & 81 & 10 & 9 & 100 \\
b) & Total Operational Cost/Farm/Day & 574.52 & 1519.99 & 3723.91 & 988.44 \\
c) & Total Return/Farm/Day & 823.05 & 2210.85 & 4497.81 & 1292.56 \\
d) & Profit/Farm/Day & 248.53 & 690.86 & 773.9 & 304.12 \\
e) & Profit/Farm/Year & 90713.45 & 252163.9 & 282473.5 & 111003.8 \\
\hline
\end{tabular}

Source: Authors Calculations Based on Field Survey

Table 9 Resource use efficiency analysis

\begin{tabular}{|c|c|c|c|c|c|c|c|c|}
\hline \multirow[t]{3}{*}{ Variables } & \multicolumn{8}{|c|}{ Categories of Dairy Farms } \\
\hline & \multicolumn{2}{|l|}{ Small } & \multicolumn{2}{|l|}{ Medium } & \multicolumn{2}{|l|}{ Large } & \multicolumn{2}{|l|}{ Pooled } \\
\hline & Coefficients & t Stat & Coefficients & t Stat & Coefficients & t Stat & Coefficients & $\mathrm{t}$ Stat \\
\hline Intercept & -1.813 & -2.784 & -9.006 & -3.203 & -4.242 & -1.001 & -1.801 & -1.733 \\
\hline Feed Cost & 1.592 & $10.010 * *$ & 3.100 & $5.224 * *$ & 1.656 & $1.919 *$ & 1.650 & $11.294 * *$ \\
\hline Miscellaneous & -0.558 & $-3.564 * *$ & -1.271 & $-2.540 * *$ & -0.288 & -0.461 & -0.599 & $-4.224 * *$ \\
\hline \multicolumn{9}{|l|}{ Expenditure } \\
\hline Labour & - & - & -0.178 & -0.515 & 0.125 & 0.764 & -0.047 & -0.270 \\
\hline Sample size & 81 & & 10 & & 9 & & 100 & \\
\hline \multicolumn{9}{|l|}{ Elasticities } \\
\hline $\mathrm{R}^{2}$ & 0.80 & & 0.87 & & 0.77 & & 0.93 & \\
\hline $\mathrm{F}$ & $156.123 * *$ & & $13.175 * *$ & & $5.474^{*}$ & & $444.336^{* *}$ & \\
\hline \multicolumn{2}{|c|}{ Standard Error 0.192} & & 0.128 & & 0.078 & & 0.182 & \\
\hline \multicolumn{2}{|c|}{ Cobb-Douglas } & \multicolumn{2}{|c|}{$\mathrm{P}(\mathrm{F}, \mathrm{M})=0.163 \mathrm{~F}^{1.592} \mathrm{M}^{-1.592}$} & \multicolumn{2}{|c|}{$\mathrm{P}(\mathrm{F}, \mathrm{M})=0.0001 \mathrm{~F}^{3.100} \mathrm{M}^{-1.271}$} & ${ }^{1}$ b $\mathrm{P}(\mathrm{F}, \mathrm{N}$ & 1) $=0.014 \mathrm{~F}^{1.656 \mathrm{~b}}$ & $\mathrm{P}(\mathrm{F}, \mathrm{M}, \mathrm{L})=0.165 \mathrm{~F}^{1.650} \mathrm{M}^{-0.559}$ \\
\hline
\end{tabular}

** Significant at 0.05 level of significance

* Significant at 0.10 level of significance 
farms. The pooled expenditure taking all the samples together was calculated as Rs. 988.44 per farm per day.

\section{Return per farm per day}

Table 7 presents the return per farm per day across different categories of commercial dairy farms in organized dairy sector. A perusal of the table shows a return of Rs. 812.68 per farm per day in small category of dairy farms, Rs. 2210.85 per farm per day in medium category of dairy farms, Rs. 4497.81 per farm per day in large category of dairy farms in the organized dairy sector. The pooled income taking the entire sample together was estimated as Rs. 1292.56 per farm per day. The income from sale of milk constituted the maximum proportion of the income (more than 98 percent) in all the categories of the dairy farm. The returns from sale of manure/cow dung and male calves also contributed to the total income but in minimal way. It can be suggested, at least for the large dairy farms, to go for preparation of vermi- compost or similar products, which will help them to derive more income from the cow dung. The earning from the sale of milk can also be increased if the dairy farmers go for some sort of processing or value addition, which was found negligible in the sample dairy farms. The above observation is very different from the Integrated Sample Survey Report, 2004-15 which reported 22 percent of milk converted into milk products in entire Assam in 2014-15.

\section{Cost and return analysis}

The cost and returns across different categories of commercial dairy farms in organized dairy sector is presented in Table 8. It was observed that the profit per farm per day increased from Rs. 248.53 from small farms to Rs. 690.86 in medium farms to Rs. 773.9 in large dairy farms. This is obvious considering the increased of herd size. The pooled profit per farm per day was estimated as Rs. 304.12. It was also observed that the profit per farm per year increased from Rs. 90713.45 from small farms to Rs. 252163.9 in medium farms to Rs. 282473.5 in large dairy farms. The pooled profit per farm per day was estimated as Rs. 111003.80 . It is heartening to see that the small and medium commercial dairy farms of Jorhat district generate more net surplus than that of commercial dairy farms of Maharastra where small category of commercial dairy farms generated a net surplus of Rs. 1,92,898 per annum and medium the medium category of farms generated a net surplus of Rs $67,216.00$. The large commercial farms with net profit of Rs. 3,12,178 per year found to be better in Maharashtra (Ghule et al. 2012). However, it is to be noted that a subsidy of Rs. 58480.00 per farm under scheme for two animals were taken by the farmers Jorhat district which will not be available for purchase of more cows. The less net surplus of large farms in Jorhat than Maharashtra may be a possible sign to explain the situation when the farms want to grow big.

Resource use efficiency of dairy farms in organized dairy sector 
The estimated resource-use efficiency of dairy farms in organized dairy sector is furnished in Table 9 . In small dairy farms the $\mathrm{R}^{2}$ value was 0.80 which indicates that 80 per cent of the variations in income from dairy farms were influenced by the explanatory variables included in the model. It is evident from Table 9 that feed cost influence was positive and significant and miscellaneous expenditure was negative and significant. Hence, increase in the use of feed would increase the revenue from dairy farms by 1.59 percent and increase in miscellaneous expenditure decreases the farm revenue by 0.56 percent.

As all the dairy farms reported to use one family labour with opportunity cost of Rs. 298.00 (minimum wage), due to lack of variation was not considered as a variable. The MVP of feed was calculated as 2.703 and MVP of miscellaneous expenditure was calculated as (-) 39.59 (Table 10). In medium dairy farms the $\mathrm{R}^{2}$ value was 0.87 which indicates that 87 per cent of the variations in income from dairy farms were influenced by the explanatory variables included in the model.It is evident from Table 9 that feed cost influence was positive and significant and miscellaneous expenditure was negative and significant. Hence, increase in the use of feed would increase the revenue from dairy farms by 3.1 percent and increase in miscellaneous expenditure decreases the farm revenue by 1.27 percent. The influence of labour was not found to be significant. The MVP of feed was calculated as 9.852 and MVP of miscellaneous expenditure was calculated as (-) 206.682 (Table 10). In large dairy farms the $\mathrm{R}^{2}$ value was 0.77 which indicates that 77 per cent of the variations in income from dairy farms were influenced by the explanatory variables included in the model. It is evident from Table 9 that feed cost influence was positive and significant. Hence, increase in the use of feed would increase the revenue from dairy farms by 1.66 percent. The influence of miscellaneous expenditure and labour was not found to be significant. The MVP of feed was calculated as -0.007 .

\section{Conclusions}

In the study area 81 dairy farmer found to be small category, ten dairy farmers were identified to be in medium category and nine dairy farmers were in large category of dairy farms. The total milk production in 100 sample dairy farms was reported as 3445 litres per day with average milk production of 8.79 litres per day per milch animal. The total milk production per day per farm in small dairy farms was observed as 21.57 litres, in medium dairy farms as 58.7 litres and in large as 123.44 litres. Overall the average milk production per farm in 100 sample households was estimated to be 34.45 litres per farm per day. With more than 94 percent of the investments the dairy cattle's especially the cross breed and Indian breed accounted for the maximum share of the investments. A return of Rs. 812.68 per farm per day in small category of dairy farms, Rs. 2210.85 per farm per day in medium category of dairy farms, Rs. 4497.81 per farm per day in large category of dairy farms was observed. The income from sale of milk constituted the maximum proportion of the income (more than 98 percent) in all the categories of the dairy farm. The returns from sale of manure/cow dung and male calves also contributed to the total income but in minimal way. It was observed that the profit per farm per day increased from Rs. 248.53 from small farms to Rs. 690.86 in medium farms to Rs. 773.9 in large dairy farms.Feed cost influence was positive and significant. Hence, increase in the use of feed would increase the revenue from dairy farms by 1.66 percent. The influence of miscellaneous expenditure and labour was not found to be significant.

\section{Acknowledgements}

This paper is part of the study conducted on the topic "Supply Chain Analysis of Organized and Unorganized Dairy Sectors: A Comparative Analysis in Jorhat District of Assam" for partial fulfilment of the PhD degree programme in Department of Rural Development and Agricultural Production, North- Eastern Hill University, Tura Campus of the first author. The authors are also grateful to ICSSR, New Delhi for providing financial assistance for conducting the research.

\section{References}

Chand K, Singh K, Singh RV (2002) Economic analysis of commercial dairy herds in arid region of Rajasthan. Indian J Agric Econ 57(2): 224-233

Chattraji J, Singh L (1989) Return to fixed capital investment through dairy cooperatives. Indian J Dairy Sci 42(3): 467-470

Cobb CW, Douglas PH (1928) A theory of production. The American Econ Review 18(1): 139-165

Dalenius T, Hodges JL (1959) Minimum variance stratification. J American Stat Assoc 54: 88-101

Dhanabalan M (2009) Productive efficiency of milk production in Tamil Nadu. Indian J Marketing 39 (12): 21

FAO (2009) The state of food and agriculture: Livestock in the balance. Rome: Food and Agriculture Organization of the United Nations

Ghule AK, Verma NK, Cahuhan AK, Pravin Sawale P (2012) An economic analysis of investment pattern, cost of milk production and profitability of commercial dairy farms in Maharashtra. Indian J Dairy Sci 65(4): 329-336

Government of Assam (2013) Progress report of dairy development in Jorhat and Golaghat District, Town Milk Supply Scheme, Jorhat, 2013

Government of India (2017) Milk Production in India. Department of Animal Husbandry, Dairying \& Fisheries, Ministry of Agriculture. Krishi Bhawan, Delhi, 2017 Retrieved from https://www.nddb.coop/ information/stats/milkprodindia)

Government of India (2018) Press Information Bureau, Ministry of Agriculture \& Farmers Welfare. Retrieved from http://pib.nic.in/ newsite/PrintRelease.aspx? relid=175649

Jaiswal P, Singh KR (2015) Economics of milk production and determinants of market participation for small holder dairy farmers in Raipur district of Chhattisgarh. Indian J Dairy Sci 68(6): 619-28

Kakaty G, Das AK (2017) Assessment of the status of dairying and potential to improve socio-economic status of the milk producers and convergence of all central and state schemes at district level in Assam (Study number 150). Sponsored by Department of Agriculture, Cooperation and Farmers' Welfare, Ministry of Agriculture and 
Farmer' Welfare, Government of India, New Delhi, and conducted by Agro-Economic Research Centre for North-East India, Assam Agricultural University, Jorhat - 13, Assam

Kakaty G, Gogoi, M. (2001) Employment and income opportunity in dairy enterprises of Assam - A case study. Agricultural situation in India 66 (2): 69

Khoveio M, Jain DK, Das, G (2016) A study on marketed surplus and disposal pattern of milk in the north- eastern state of Nagaland. Indian J Dairy Sci 69(1): 94-97

Pant SP, Karanjkar SV (1965) Economics of dairy enterprise in Jabalpur with special reference to the scale of enterprise. Indian J Agric Econ 20(1):116-121

Ramakrishnappa V, Jagannatha RR (2006) Emerging microfinance issues in dairy development: A case study from Karnataka, India. Int J Agric Resour Governance Ecol 5(4): 399-412

Ramphul (2011) Productivity and efficiency analysis of Haryana's dairy industry. Productivity 52(1): 42-50

Ramphul (2012) Globalization and world dairy trade: An assessment. The J World Investment Trade 13(1): 77-103

Reserve Bank of India (2017) Interest Subvention Scheme for Short Term Crop Loans during the year 2017-18. RBI, RBI/2017-18/48 dated $16^{\text {th }}$ August, 2017 retrieved from https://rbidocs.rbi.org.in/rdocs/

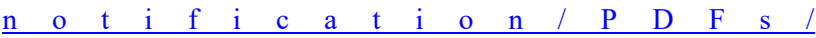
NOTI48EA7D9A680B574A57A68535D992A54795.PDF

Singh JK, Singh R, Singh JP, Mishra SK, Kumar R, Raghuvanshi, T (2017) A study of the cost and returns of milk production of cow and buffalo and to find out the break-even point of dairy enterprise in Faizabad district of eastern Uttar Pradesh, India. Int J Current Microbiol Appl Sci 6(11): 3928-3938

Singh M, Joshi AS (2008) Economic analysis of crop production and dairy farming on marginal and small farms in Punjab. Agric Econ Res Rev 21(2): 30

Singh R, Chauhan AK, Yogi RK (2014) Economic analysis of milk production and its disposal pattern in IDDP area of Meghalaya State. Indian J Dairy Sci 67(1): 74-82

Sirohi S, Kumar A, Staal SJ (2009) Formal milk processing sector in Assam: Lessons to be learnt from institutional failure. Agric Econ Res Rev 22(2): 245-254

The Hindu (2017, December, 28) India leads in global milk production. Retrieved from https://www.thehindu.com/news/national/india-leadsin-global-milk-production/article22320382.ece 